\title{
Development of Mathematics Based Learning Realistic Mathematics For Improving Metacognition Skills and Students Creative Thinking
}

\author{
Yunita Sipahutar \\ Department of Mathematics Education \\ State University of Medan \\ Medan, Indonesia \\ Corresponding email: Nitay4811@gmail.com \\ Bornok Sinaga \\ Department of Mathematics Education \\ State University of Medan \\ Medan, Indonesia \\ Mulyono \\ Department of Mathematics Education \\ State University of Medan \\ Medan, Indonesia
}

\begin{abstract}
The purpose of this research is to develop learning device on mathematics learning using realistic mathematics learning in Class XII SMK, with this tool is expected to change the paradigm of learning "centered on teacher" to "student-centered". This research is a research development (Reasearch and Development) using qualitative descriptive method, and through developmental test which refers to Four-D Thiagarajan model (1994), that is difine, design, develop, and disseminate stage. The results of the study show that are learning tools developed meet the criteria of valid, practical and effective, the ability of teachers in managing learning "good" category, student activity in effective category, positive teachers, metacognition ability and student reative thinking are also good.

Keyword: metacognition, creative and realistic mathematics learning
\end{abstract}

\section{INTRODUCTION}

Mathematics is the key to science. The phrase is true given the facts of many historical records that computer science will not develop as sophisticated as if previously not justified binary numbers (Yusri: 2012). Astronomers also can not determine the distance between stars if previously not introduced binary numbers (Yusri: 2012). Astronomers are also unlikely to determine the distance between stars if they were not introduced trigonometry, and much more. However, it should be emphasized here that the mathematical concept that has been possessed is not the only important factor supporting science.

Mathematical fikir pattern that makes a considerable contribution in developing mathematics learning science has a function as a means to develop mathematical fikir pattern that is: critical thinking ability, logical, creative and cooperate that required students in modern life as stated in one of the goals of learning mathematics

\section{METHOD}

This research includes development research using Thiagarajan learning device development model (1974: 36). Learning tools that will be developed in this research are realistic based learning tools which include lesson plan, Student Book (BS), Learning Implementation Plan (RPP) and Student Activity Sheet (LAS). In addition to developing the tools in this study also developed research instruments that include: learning ability test sheets, student activity observation sheets, learning management observation sheets, student response sheets, and learning device validation sheets. In detail the stages of development namely: (1) student activity, (2) learning management, (3) student response, (4) teacher response, (5) student response, 6) test learning outcomes.

\section{RESULTS}

Students respond very happy to use validation result validation instrument instrument of learning in the form of Learning Implementation Plan (RPP), student book, test result of learning in the form of metacognition ability ability and student creativity ability, validation sheet of learning device implementation, teacher response questionnaire vaccination sheet, validation student response questionnaires, student 
activity validation sheets and validation sheet of teachers' ability to manage learning shows all these instruments are valid. To know the effectiveness of learning device is done by giving test result of learning mathematics to student.

From the results of pre-Test obtained the average class of mathematical metacognition results of 59.08 with a presentation of $9.38 \%$ completeness (3 students from 32 students) from the results of post-test to students obtained an average score of 73.44 students in classical thoroughness $87.50 \%$ (28 students from 32 students). means learning devices using realisti mathematical approach has contributed to improve students' mathematical metacognition abilities. it can be seen that students' learning completeness criteria at TKMMyaitu number of complete student learn as much as 28 student $(73,68 \%)$ from 38 student. While the number of students who do not complete is as many as 10 students $(26.32 \%)$ of 38 students. Furthermore, classically that a learning is said to have reached completeness, if there are $85 \%$ of students who follow the meacognition and creative mathematics achieves a minimum score of 2.67. Maskiness classically on student TKMM result of $73,68 \%$. Thus classically on the results of TKMM, students' metacognition and creative math skills have not met the criteria of completeness.

The result of the research by Siswono (2004: 9), stated that the result of data capability of the task of filing the problem from each of the research groups produced showed that tend to be in the group 'less creative', that is to fulfill one or two creative product criteria that is novelty, or flexibility. It is seen from the average result obtained on the indicator is 4.00. In addition, the indicators plan and perform problem solving, $67.25 \%$ of students have been able to determine the problem resolution plan as well as solve the problems presented. However, on the reexamination indicator, it was found that $30.25 \%$ of students still have difficulty in doing a re-examination of the results that have been obtained. It is seen from the average value obtained on the indicator that is 1.21 is still far from the minimum completeness criteria (greater or equal to 2.67). This is in accordance with research Nool (2012) which reveals that realistic learning effectively develops students' metacognition abilities in problem solving. it can be concluded that teachers' ability to manage learning at first and second meetings in the first field trials is in the "good enough" category (2.50-3.49). Thus, the overall average ability of teachers in managing learning is in the category of "good enough" (2.50-3.49). The ability of teachers to manage learning is said to be effective when the average ability of teachers for all meetings reaches a minimum of good criteria (as outlined in Chapter III). Because in both meetings the average value of 3,1125 can be concluded that the ability of teachers to manage learning has not been effective. it can be seen that the average percentage of students respondents express happy about teaching materials, student books, worksheets, learning atmosphere and how teachers teach is equal to $81.054 \%$. While the states are not happy is equal to $18.956 \%$.
The average percentage of students respondents stated that the teaching materials, student books, LKS, learning atmosphere and the way teachers teach them new things is $75.262 \%$. While that states is not a new thing is equal to $24.738 \%$. The average percentage of students respondents stated that interested in following the learning process as it has been obtained is equal to $73.68 \%$. The average percentage of students respondents who stated no interest was $21.05 \%$. The average percentage of students 'responses to language, illustrations of drawings, writings and other appearances on student books, and LKS is $82.89 \%$ said to understand the language in the students' books and LKS and feel interested in his appearance. While the average percentage of student responses who do not understand the language in the book students and LKS and do not feel interested in appearance is $17.11 \%$.

In accordance with the results of research Zakiya (2013) showed that (1) The effectiveness of learning tools developed using Realistic Mathematics Learning to the ability of mathematical metacognition concluded based on student learning a.ketuntasan in classical $b$. The achievement of the indicators lies in the criteria of effectiveness limits (2) The improvement of students' mathematical communication ability toward learning devices developed using PMR is known from the average of the increase of mathematical metacognition ability of the students in experiment $I$ that is 0,61 increased to 0.65 in the II and III trials. Student responses to the components and learning activities using PMR are positive

\section{CONCLUSIONS}

Based on the successes and discussions in this research, the following concepts are presented:1. Based on the development of learning tools using a modified 4-D model, valid learning tools are valid. The learning tools consist of: (1) Learning Device Plan (RPP); (2) Student Book (BS); (3) Student Activity Sheet (LAS); (4) Metacogical Capability Test (TKM); and (5) Creativity Test (TKK) which can be seen in the appendix. 2. The effectiveness of PMR-based learning tools developed has met the effective criteria indicated by students' classical completeness fulfilled, the student's active activity within defined tolerance limits, the student's response to the components of learning tools and positive learning activities.3. Improvement of Metacognition skills of students using learning tools based on PMR developed is the average achievement of students' metacognition ability in the first test of 80.78 increased to 84.71 on trial II and the average of each indicator of Metakogni sisiswa increased ability from the trial I test II.4.

Improving the ability Student's mathematical creativity using learning tools based on PMR developed is the average achievement of the ability of students 'mathematical creativity on the first test of 77.19 increased to 80.88 on trial II and the average of each indicator of students' mathematical creativity increased from trial I to test II.5. The process of student answers on trial II is better than the student's answer process on trial I. 


\section{REFERENCES}

[1] Akker, J. Van den. 1999. Principle and Methods of Development, In: J. Van den

[2] Arends, R.I. 2008. Learning to Teach, Learning to Teach The Seventh Edition Volume Two. Translation by Soedjipto, Helly, P. and Soedjipto, Sri, M. Yogyakarta: Student Library

[3] Akker, R. Branch, K. Gustafson, N. Nieveen \& Tj. Plomp (Eds), Design Methodology and Development Research. Dordrecht: Kluwer.

[4] Ali, Muhammad. 1987. Teacher In Teaching and Learning Process. Jakarta. Rays

[5] Armanto, Dian. 2001. Learning Flow Multiplication and Division of Two Figures in Realistic Mathematics Education (PMR). The seminar paper is presented at the National Seminar in Yogyakarta.

[6] Arikunto, Suharsimi. 2002. Research Procedure (A Practice Approach). Revised Edition V. Rineka Cipta. Jakarta. 